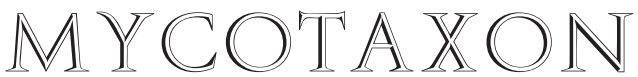

DOI: $10.5248 / 113.101$

Volume 113, pp. 101-109

July-September 2010

\title{
Glomus candidum, a new species of arbuscular mycorrhizal fungi from North American grassland
}

\author{
Eduardo Furrazola, Ricardo Herrera-Peraza ${ }^{\S}$, \\ Instituto de Ecología y Sistemática, IES-CITMA \\ A.P. 8029, C. de La Habana 10800, Cuba \\ Wittaya Kaonongbua \& James D. BeveR* \\ *jbever@indiana.edu \\ Department of Biology, Indiana University \\ Bloomington, IN 47405, U.S.A.
}

\begin{abstract}
A new species of arbuscular mycorrhizal fungi, Glomus candidum is described. The species produces spores singly in the soil. Spores are white to very pale yellow, usually globose to subglobose, $87-157 \mu \mathrm{m}$ diam. Spore wall consists of two adherent layers. The outer layer is hyaline, mucilaginous, and stains very pale pink in Melzer's reagent. This layer can be observed in young spores and often degrades at maturity. The inner layer is hyaline and laminated, but occasionally the innermost group of laminae are pigmented a pale yellow to give the impression of two separated layers.

Resumen - Se describe una nueva especie de hongo formador de micorrizas arbusculares, Glomus candidum. La especie produce esporas libres en el suelo. Las esporas son blancas a amarillo muy pálido, usualmente globosas a subglobosas, 87-157 $\mu \mathrm{m}$ de diámetro. La pared de la espora consiste en dos capas adherentes. La capa externa a menudo se degrada con la madurez, es hialina, mucilaginosa, y se tiñe, sólo en las esporas jóvenes, de rosado muy pálido en reactivo de Melzer. La capa interna es hialina y laminada, pero a veces el grupo más interno de láminas aparece pigmentado de amarillo claro dando la impresión de dos capas separadas.
\end{abstract}

Key words - classification, molecular phylogeny, species description, taxonomy

\section{Introduction}

In studies of arbuscular mycorrhizal (AM) fungal ecology in an old field plant community on the campus of Duke University in Durham, North Carolina, a new species of Glomus was discovered with spores that were white to opaque

\footnotetext{
$\S$ Deceased
} version was published with halftone (grayscale) plates. 
when old (Bever et al. 1996, 2001). This fungus was subsequently used in multiple experiments on plant-soil feedback (Bever 2002), context dependence of plant growth promotion (Reynolds et al. 2005, Reynolds et al. 2006), effects on plant tolerance and defense against above-ground herbivores (Bennett \& Bever 2007, Bennett et al. 2009), fungal competition (Bennett \& Bever 2009) and preferential plant allocation (Bever et al. 2009). In the present paper, we describe this as a new species, Glomus candidum, sp. nov. based on morphology of mature spores as defined for the genus Glomus by Morton (1996) and Stürmer \& Morton (1997), and the molecular studies of sequence from the large subunit (LSU) of the nuclear ribosomal (nrRNA) gene.

\section{Materials and methods}

Samples consisting of soil and roots fragments were collected from the rhizosphere of Allium vineale L., Anthoxanthum odoratum L., Plantago lanceolata L. and Panicum sphaerocarpon Elliott growing in the field plot. Soils were mixed 1:1 (v/v) with silica sand that had been autoclaved for 1 hour at $120^{\circ} \mathrm{C}$, then placed in greenhouse Deepots ${ }^{\mathrm{wt}}$ (Stuewe and Sons, Corvallis, OR), and seeded with either Sorghum halepense (L.) Pers. or Sorghum bicolor (L.) Moench separately. In addition, rhizosphere soil was collected to establish trap cultures using the above field plant species as hosts as described by Bever et al. (1996). Cultures were maintained in a cool season greenhouse $\left(4-21^{\circ} \mathrm{C}\right)$ at Duke University. After $20 \mathrm{wk}$ and once dried in situ, pot contents were harvested and stored at $4^{\circ} \mathrm{C}$ for $2 \mathrm{mo}$. Sporulation of the new Glomus sp. was particularly abundant with Pa. sphaerocarpon (note Glomus candidum = Gl. sp. D1 in Bever et al. 1996, = Gl. "white" in Bever et al. 2009, = Gl. hyalinulum (ined.) in Msiska \& Morton 2009).

Spores were extracted from soil by wet sieving and decanting followed by centrifugation in a $20-60 \%$ sucrose density gradient (Daniels \& Skipper 1982). Healthy spores were pipetted onto roots of 10-12 d old S. bicolor seedlings. Each inoculated seedlings were then transplanted into $4 \times 21 \mathrm{~cm}$ Cone-tainers ${ }^{\mathrm{mw}}$ (Stuewe and Sons, Corvallis, OR) containing a sterile loamy soil:sand mix (1:2 v/v), adjusted to $\mathrm{pH} 6.2$ and grown for $120 \mathrm{~d}$ in a growth room at the International Culture Collection of (Vesicular) Arbuscular Mycorrhizal Fungi (INVAM) at West Virginia University with a temperature range of $21-28^{\circ} \mathrm{C}, 225 \mu \mathrm{mol} \mathrm{m}^{-2} \mathrm{~s}^{-1}$ light intensity and a 14 -h photoperiod.

Once monospecific cultures of $G$. candidum was successfully established, the contents of selected Cone-tainers ${ }^{\mathrm{mw}}$ were placed in the center of $15-\mathrm{cm}$ pot, surrounded with the same growth medium described earlier, seeded with sudan grass (Sorghum sudanense (Piper) Stapf and grown for another five months. This isolate (deposited in INVAM as NC268) and single spore cultures, maintained as pure cultures for more than ten years in the Bever lab collection, were used to describe the new species, G. candidum.

Spore size was measured with an ocular micrometer and color of spores was determined under reflected light from a two-branch fiber optic illuminator (color temp $3400 \mathrm{~K}$ ) to co-illuminate spores and a printed color chart (INVAM color chart). The colors on the chart were composed of various percentages of the component colors: cyan, magenta, yellow and black. Spores were preserved in $0.05 \% \mathrm{NaNO}_{3}$ at $4^{\circ} \mathrm{C}$. 
Spores were also mounted in polyvinyl alcohol lacto-glycerol (PVLG) (Koske \& Tessier $1983)$ and PVLG mixed with Melzer's reagent (1:1 v/v) to observe and measure spore subcellular structures. Slides of the spores were incubated in a conventional oven at $65^{\circ} \mathrm{C}$ for $24-48$ hours and deposited as permanent vouchers at Oregon State University (OSC), Corvallis, OR; Harvard University (FH), Cambridge, MA; INVAM, the Bever lab collection and personal collection of W. Kaonongbua. Selected images of the spores were captured by a Sony CCD video camera on a Nikon Eclipse E600 Microscope. Color images in this paper are available from the corresponding author upon request.

The LSU nrRNA gene sequence (GU980757) was obtained from a single spore of the new fungus and was similarly subjected to various analyses (BLAST search, similarity index) as previously described (Kaonongbua et al. 2010). Additional LSU nrRNA sequences broadly representing the phylum Glomeromycota and outgroups (Mortierella polycephala - AF113464 and Basidiobolus ranarum - AF113452) were acquired from the NCBI's GenBank and then aligned using Clustal X (v. 2.0) (Larkin et al. 2007). After manual inspection and editing, a phylogenetic reconstruction based on the NeighborJoining (NJ) method with Kimura's 2-paremeter model of nucleotide substitution was performed using MEGA4 (Tamura et al. 2007) with 1000 bootstrap replications.

\section{Taxonomy}

Glomus candidum Furrazola, Kaonongbua \& Bever, sp. nov.

FIG. 1

MrcoBank MB516798

Sporocarpia ignota. Sporae in solo singilatim efformatae, terminales, globosae vel subglobosae, 87-157 $\mu \mathrm{m}$ diam., candidus vel pallide luteae. Sporae tunica strata duabus: stratis exterior hyalino, inmundo, caduco, 1.7-4.3 $\mu \mathrm{m}$ crasso; stratis secundo hyalinae vel pallide lutei, subtiliter laminato, 3.7-9.4 $\mu \mathrm{m}$ crasso. Hyphae subtendentes 6-21 $\mu \mathrm{m}$ diam., rectae vel recurvatae, porus septatus. Hyphae tunica strata duabus. Mycorrhizae vesiculararbusculares formans.

Holotype: UNITED STATES. NORTH CAROLINA: Durham County on Duke University Campus, from an old field on the corner of Alexander Drive and University Avenue. September 1992, JD Bever, from culture IU-06. Deposited at OSC as broken spores mounted permanently on a glass slide, and labeled as 'holotype.'

EтумоLogy: from the Latin: 'candidus' (white) referring to the white color of the spores under stereomicroscope.

Spores formed singly in soil and roots; globose to subglobose, 87-157 $\mu \mathrm{m}$ diam (mean $=125 \mu \mathrm{m}, \mathrm{n}=125)$; white, with a few spores becoming a pale yellow color (0-0-5-0) with age. Spores have a thin "halo" under reflected light (FIG. 1.1) when all spore wall layers are present. The spore wall consists of two adherent layers (FIGs. 1.2-1.3). The outer layer (L1) is hyaline, mucilaginous initially, becoming more granular as it begins to decompose, 1.7-4.3 $\mu \mathrm{m}$ thick, often adherent to the inner structural laminate layer, staining very pale pink in Melzer's reagent in juvenile spores only. With age, this layer degrades and decomposes naturally, after which it appears granular and may accumulate some debris. The inner layer (L2) is laminated, 3.7-9.4 $\mu \mathrm{m}$ thick (mean $=6.1$, 

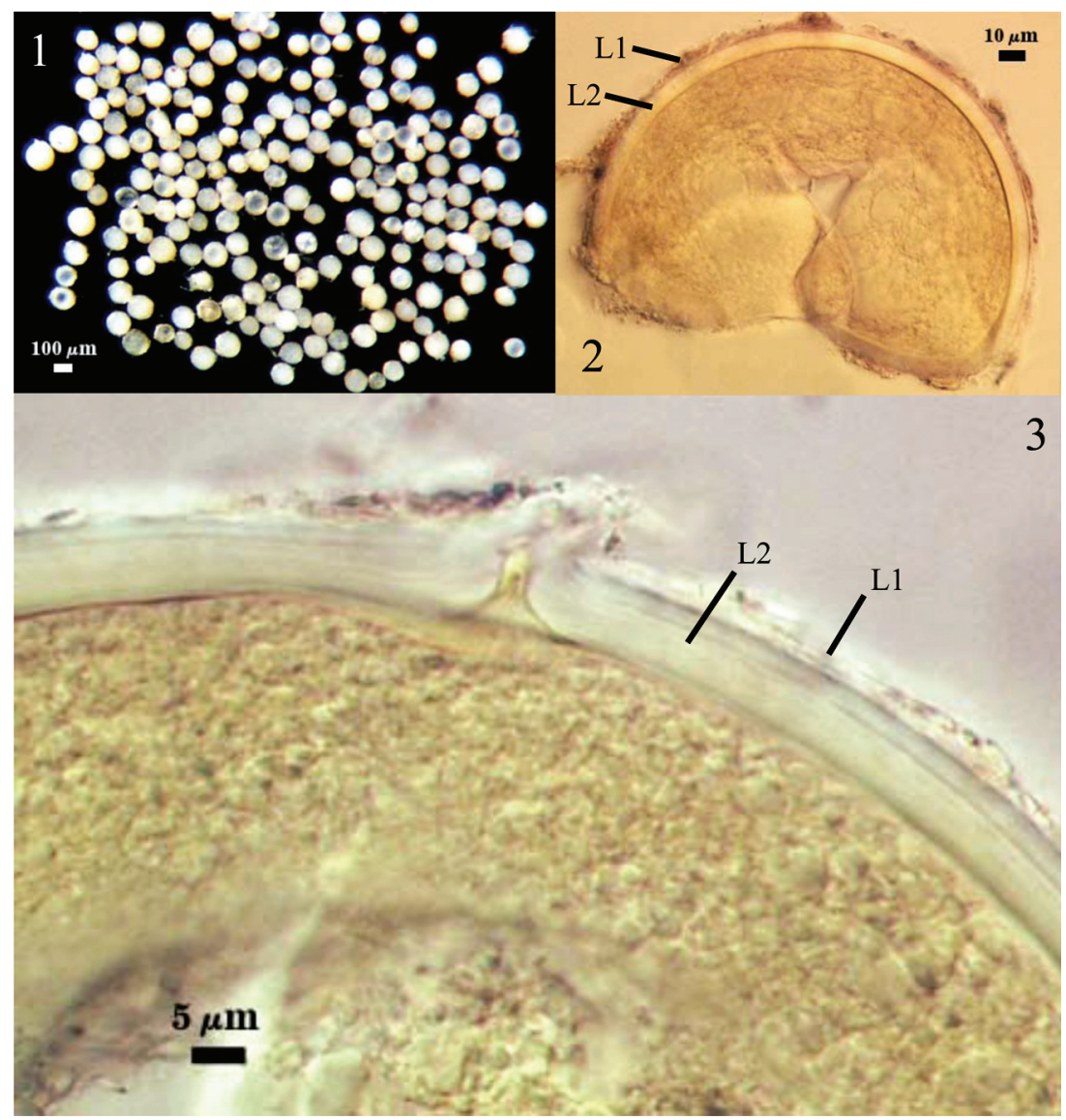

FIGURE 1. Glomus candidum, Reference Accession NC268. 1, Color and shape of spores under the dissecting microscope; note the halo around some spores. 2, Spore wall composed by two layers (L1 and L2). 3, A larger magnification showing an improved view of wall composition.

$\mathrm{n}=40$ ). It is often uniformly hyaline, but in a few spores, an innermost group of laminae (sublayers) is pigmented a pale yellow (0-15-0-0) to give the appearance of two separates layers of occasionally equal thickness. This color separation is not consistent in all spores. No part of the laminate layer reacted in Melzer's reagent. Subtending hyphae is single, straight or occasionally recurved, cylindrical to slightly flared, 6-21 $\mu \mathrm{m}$ wide at spore base. Some spores lack the subtending hyphae due to breakage close to the spore base. In mature spores, the innermost sublayer(s) of the laminate layer of the spore wall, usually forms a thin septum (1.0-1.7 $\mu \mathrm{m}$ thick); positioned 2-16 $\mu \mathrm{m}$ in the hyphal lumen. In 
some spores, the occlusion is a hyaline plug, or the lumen of subtending hyphae remains open. The subtending hyphal wall consists of a continuation of both layers of the spore wall. The L2 layer tapers gradually to $1 \mu \mathrm{m}$ thick, 20-25 $\mu \mathrm{m}$ from the spore base.

MyCORRHIZAE: G. candidum has been observed to form arbuscules and vesicles typical of Glomeraceae.

Distribution AND habitat: This species is known from an old field on the campus of Duke University, Durham County, North Carolina. Soil pH in this field averaged 5.2. Soil phosphorus ranged from 7.6 to $48.9 \mathrm{~kg} \cdot \mathrm{ha}^{-1}$ and averaged $17.8 \mathrm{~kg} \cdot \mathrm{ha}^{-1}$. The average percent organic matter at the sampling sites was 4.2 and the range varied from 1.07 to 14.13 . Fungi with similar morphology have also been isolated from Indiana, Maryland, and West Virginia.

Mycorrhizal associations: Found in the rhizosphere of Al. vineale, An. odoratum, Pl. lanceolata, and Pa. sphaerocarpon in the field plot. Formed arbuscular mycorrhizae on S. bicolor, S. halepense, S. sudanense, and Zea mays in greenhouse-grown pot cultures.

Molecular phylogenetic analysis: The LSU nrRNA gene tree clearly places the new fungus as a member of the Glomus group B (Schwarzott et al. 2001) along with sequences from Glomus claroideum N.C. Schenck \& G.S. Sm., Glomus etunicatum W.N. Becker \& Gerd., and Glomus luteum L.J. Kenn. et al. and with 100\% statistical support (FIG. 2).

\section{Discussion}

Our phylogenetic analysis of the LSU nrRNA gene sequences placed G. candidum in Glomus Group B sensu Schwarzott et al. (2001). This is consistent with the phylogeny generated by the $\beta$-tubulin gene using an isolate of $G$. candidum from Maryland (Msiska \& Morton 2009). Both of these studies were limited by using only a single sequence from a single spore of the new AM fungal species. Thus the molecular work cannot test the extent of genetic divergence within this species or between G. candidum and other species in this clade.

Spores of G. candidum differ in morphology from other species in Glomus Group B, including G. claroideum, G. lamellosum Dalpé et al., and G. luteum. Spore size range of G. candidum overlaps with that of G. claroideum (87-157 and 70-180 $\mu \mathrm{m}$, respectively); however, both species differ in their spore ontogenies. Whereas fully formed spores of $G$. claroideum show four layers (Stürmer \& Morton 1997), spores of G. candidum develop only two layers. Occasionally, the innermost group of laminae (sublayers) of G. candidum spore wall layer 2 may appear as a separate layer due to slight pigmentation. In addition, the pore of the subtending hypha of G. claroideum spores is occluded either by a sublayer (lamina) of the laminate spore wall layer 3 and spore wall 
106 ... Furrazola \& al.

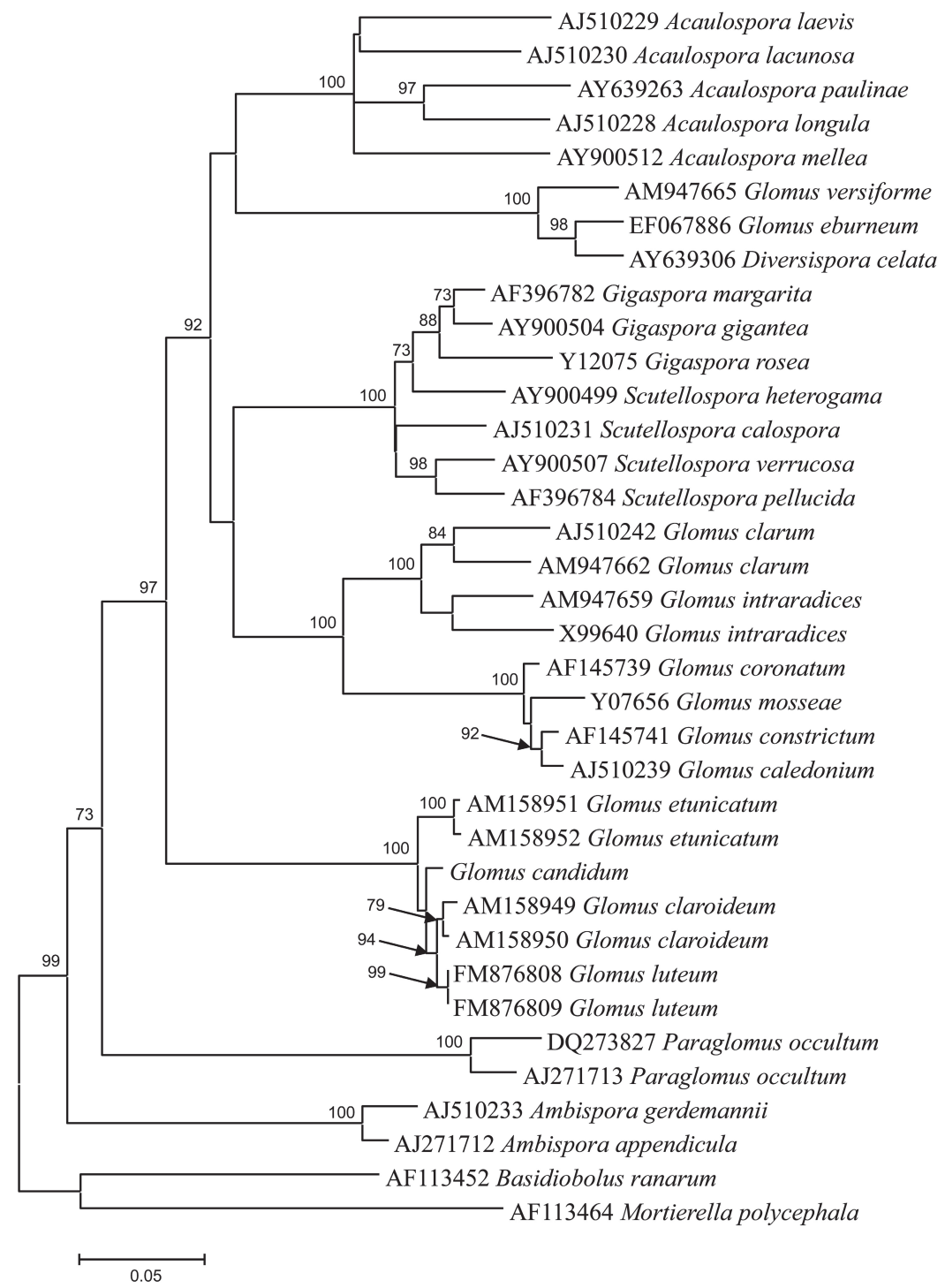

FIGURE 2. Neighbor-joining tree inferred from partial nrLSU sequences showing the taxonomic position of Glomus candidum as a member of the Glomus "Group B". The numbers on the tree braches are bootstrap support values based on 1000 replications of the neighbor-joining analysis (values are not shown if it is below 70\%). Sequences of Mortierella polycephala (AF113464) and Basidiobolus ranarum (AF113452) were used as outgroups. The scale indicates the number of base substitutions per site. 
layer 4 or only by spore wall layer 4 . In contrast, in G. candidum the closure is by the presence of a thin septum or a mucilaginous plug.

When viewed under a dissecting microscope, G. candidum spores also resemble those of G. lamellosum because of their similar size range (87-157 and 98-142 $\times 122-162 \mu \mathrm{m}$, respectively) and their whitish to pale yellow pigmentation (Dalpé et al. 1992). However, G. lamellosum spores have been described with a spore wall composed of three layers persisting in mature spores, with the outermost one significantly thicker than the first layer of G. candidum (4-14 $\mu \mathrm{m}$ and 1.7-4.3 $\mu \mathrm{m}$ thick, respectively) and the flexible innermost layer not observed in the species being described here.

Glomus luteum forms spores slightly bigger than those formed by G. candidum (up to $180 \mu \mathrm{m}$ in diam) and G. luteum spores have been described with four layers, including a flexible innermost layer (Kennedy et al. 1999), which is lacking in the spore wall of G. candidum. In addition, G. luteum spores have been described as pale yellow to dark yellow with a brownish tint in color compared to the white spores of G. candidum. With age, spores of G. candidum may turn pale yellow, but examinations of crushed spores under a compound microscope can readily separate G. candidum from the three species listed above based on the number of layers of their spore wall. In addition, in PVLG + Melzer's, the outermost layer of G. candidum reacts very pale pink while the reactions are darker pink in G. claroideum, pinkish-red in G. luteum and nonreactive in G. lamellosum.

Spores of G. candidum bear superficial similarity to other phylogenetically unrelated Glomus species producing white/hyaline spores, including G. diaphanum J.B. Morton \& C. Walker, G. clarum T.H. Nicolson \& N.C. Schenck, and G. manihotis R.H. Howeler et al. under a stereomicroscope. The spore wall structure of G. candidum was initially judged most similar to G. diaphanum according to Bever et al. (1996). However, even though spore wall layers 1 and 2 of both species are similar in their phenotypic and biochemical properties, the latter species also has a flexible layer 3 in the spore wall, which is missing in the former species.

On the rare occasions in which the innermost group of laminae (sublayers) of spore wall layer 2 of G. candidum is pigmented, its spore can resemble those of G. clarum and G. manihotis (Stürmer \& Morton 1997). This can be particularly difficult to discern under low magnification, but G. candidum spores never reach as dark a tint as do those of G. clarum and G. manihotis. Spores of G. clarum and G. manihotis are also bigger (up to $260 \mu \mathrm{m}$ in diam) than those of G. candidum, whose biggest spores reach approximately $160 \mu \mathrm{m}$ in diam. In addition, in G. clarum and G. manihotis the external mucilaginous layer reacts strongly in Melzer's reagent (pinkish-red to light purple), while the reaction of the same layer in G. candidum is very pale pink and only occurs in juvenile 
spores. Finally, molecular tools clearly identify that G. candidum is a member of Glomus group B, while G. diaphanum, G. clarum, and G. manihotis are in Glomus group A sensu Schwarzott et al. (2001) (Msiska \& Morton 2009).

\section{Acknowledgments}

We acknowledge the support of ACLS-SSRC "Working Group on Cuba Social Science Research Council" as part of the project "Basic and Applied Research on the Ecology and Diversity of Mycorrhizal fungi: A proposal for Strengthening Collaborations between Cuban and US Scientists" to EF, RHP and JDB. JDB also acknowledges supports from the US National Science Foundation (NSF) grants DEB-0049080 and DEB-0616891 and from the Inter-American Institute for Global Change Research (IAI) grant CRN2014, which is supported by the US NSF (grant GEO-04523250). WK acknowledges funding from the DPST program from the Royal Thai Government and Indiana University's Floyd fellowship. We are grateful to Dr. Joseph Morton for his thoughtful discussion and for allowing the authors to use the INVAM facilities and we thank Drs. Janusz Błaszkowski and Marta Cabello for their comments on the manuscript. We also thank Edward T. Kim and Ian M. Doig for their help with manuscript preparation.

\section{Literature cited}

Bennett AE, Bever JD. 2007. Mycorrhizal species differentially alter plant growth and response to herbivory. Ecology 88: 210-218. doi:10.1890/0012-9658(2007)88[210:MSDAPG]2.0.CO;2

Bennett AE, Bever JD. 2009. Trade-offs between arbuscular mycorrhizal fungal competitive ability and host growth promotion in Plantago lanceolata. Oecologia 160: 807-816. doi:10.1007/ s00442-009-1345-6

Bennett AE, Bever JD, Bowers MD. 2009. Arbuscular mycorrhizal fungal species suppress inducible plant responses and alter defensive strategies following herbivory. Oecologia 160: 771-779. doi:10.1007/s00442-009-1338-5

Bever JD. 2002. Host-specificity of AM fungal population growth rates can generate feedback on plant growth. Plant and Soil 244: 281-290. doi:10.1023/A:1020221609080

Bever JD, Morton JB, Antonovics J, Schultz PA. 1996. Host-dependent sporulation and species diversity of arbuscular mycorrhizal fungi in a mown grassland. Journal of Ecology 84: 71-82. doi: $10.2307 / 2261701$

Bever JD, Richardson SC, Lawrence BM, Holmes J, Watson M. 2009. Preferential allocation to beneficial symbiont with spatial structure maintains mycorrhizal mutualism. Ecology Letters 12: 13-21. doi:10.1111/j.1461-0248.2008.01254.x

Bever JD, Schultz PA, Pringle A, Morton JB. 2001. Arbuscular mycorrhizal fungi: More diverse than meets the eye, and the ecological tale of why. Bioscience 51: 923-931. doi:10.1641/00063568(2001)051[0923:AMFMDT]2.0.CO;2

Dalpé Y, Koske RE, Tews LL. 1992. Glomus lamellosum sp. nov.: a new Glomaceae associated with beach grass. Mycotaxon 43: 289-293.

Daniels BA, Skipper HD. 1982. Methods for the recovery and quantitative estimation of propagules from soil. 29-35, in NC Schenck (ed.), Methods and principles of mycorrhizal research. St. Paul, Minnesota, USA, American Phytopathology Society Press. 
Kaonongbua W, Morton JB, Bever JD. 2010. Taxonomic revision transferring species in Kuklospora to Acaulospora (Glomeromycota) and a description of Acaulospora colliculosa sp. nov. from field collected spores. Mycologia, Published Online: May 26, 2010. doi:10.3852/10-011

Kennedy LJ, Stutz JC, Morton JB. 1999. Glomus eburneum and G. luteum, two new species of arbuscular mycorrhizal fungi, with emendation of G. spurcum. Mycologia 91: 1083-1093. doi: $10.2307 / 3761638$

Koske R, Tessier B. 1983. A convenient, permanent slide mounting medium. Newsletters of Mycological Society of America 34: 59.

Larkin MA, Blackshields G, Brown NP, Chenna R, McGettigan PA, McWilliam H, Valentin F, Wallace IM, Wilm A, Lopez R, Thompson JD, Gibson TJ, Higgins DG. 2007. Clustal W and clustal X version 2.0. Bioinformatics 23: 2947-2948. doi:10.1093/bioinformatics/btm404

Morton JB. 1996. Redescription of Glomus caledonium based on correspondence of spore morphological characters in type specimens and a living reference culture. Mycorrhiza 6: 161-166. doi:10.1007/s005720050121

Morton JB, Walker C. 1984. Glomus diaphanum - A new species in the Endogonaceae common in West Virginia. Mycotaxon 21: 431-440.

Msiska Z, Morton JB. 2009. Phylogenetic analysis of the Glomeromycota by partial beta-tubulin gene sequences. Mycorrhiza 19: 247-254. doi:10.1007/s00572-008-0216-Z

Reynolds HL, Hartley AE, Vogelsang KM, Bever JD, Schultz PA. 2005. Arbuscular mycorrhizal fungi do not enhance nitrogen acquisition and growth of old-field perennials under low nitrogen supply in glasshouse culture. New Phytologist 167: 869-880. doi:10.1111/j.14698137.2005.01455.x

Reynolds HL, Vogelsang KM, Hartley AE, Bever JD, Schultz PA. 2006. Variable responses of old-field perennials to arbuscular mycorrhizal fungi and phosphorus source. Oecologia 147: 348-358. doi:10.1007/s00442-005-0270-6

Schwarzott D, Walker C, Schussler A. 2001. Glomus, the largest genus of the arbuscular mycorrhizal fungi (Glomales), is nonmonophyletic. Molecular Phylogenetics and Evolution 21: 190-197. doi:10.1006/mpev.2001.1007

Stürmer SL, Morton JB. 1997. Developmental patterns defining morphological characters in spores of four species in Glomus. Mycologia 89: 72-81. doi:10.2307/3761174

Tamura K, Dudley J, Nei M, Kumar S. 2007. MEGA4: Molecular evolutionary genetics analysis (MEGA) software version 4.0. Molecular Biology and Evolution 24: 1596-1599. doi:10.1093/ molbev/msm092 
